\begin{tabular}{l|l|l} 
Jurnal Eksplorasi Akuntansi & $\begin{array}{l}\text { e-ISSN : 2656-3649 (Online) } \\
\text { Vol. 3, No 3, Agustus 2021, Hal 611-623 }\end{array}$ & $\begin{array}{l}\text { http://jea.ppj.unp.ac.id/index.php/jea/index } \\
\text { Vol }\end{array}$
\end{tabular}

\title{
Faktor-Faktor yang Mempengaruhi Tingkat Pengungkapan Wajib LKPD Kabupaten/Kota di Kalimantan Selatan
}

\author{
Shindy Putri Pramesti ${ }^{*}$, Alfian Misran ${ }^{2}$ \\ 1,2 Fakultas Ekonomi dan Bisnis, Universitas Lambung Mangkurat \\ *Korespondensi: shindyputri295@gmail.com
}

\begin{abstract}
This study tested and proved the effect of intergovernmental revenue, regional wealth, regional expenditure, and human development index on the level of mandatory disclosure of local government financial statements in South kalimantan. The independent variables in this study is intergovernmental revenue, regional wealth, regional expenditure, and human development index. Meanwhile, the dependent variable in this study is level of mandatory disclosure of local government financial statements. Population of this research covers 13 districts and cities within South Kalimantan in the period 2015-2018. The sample was selected using purposive sampling method and obtain of 52 local government financial statements. The analysis technique used on this study is multiple linear regression by SPSS 25 program. The result showed the variable intergovernmental revenue have effect on the level of mandatory disclosure. Variable regional wealth, regional expenditure and human development index do not have effect on the level of mandatory disclosure. This study also indicate that average of mandatory disclosure in South Kalimantan province is 77,98\%.
\end{abstract}

Keywords: mandatory disclosure; intergovernmental revenue; regional wealth.

How to cite (APA $6^{\text {th }}$ style)

Pramesti, S. T. \& Misran, A. (2021). Faktor-Faktor yang Mempengaruhi Tingkat Pengungkapan Wajib LKPD Kabupaten/Kota di Kalimantan Selatan. Jurnal Eksplorasi Akuntansi. 3(3). 611-623.

\section{PENDAHULUAN}

Setelah revormasi Indonesia menerapkan sistem desentralisasi dalam pelaksanaan pemerintahan. Menurut Undang-Undang Nomor 23 tahun 2014 tentang pemerintah daerah penyelenggaraan pemerintah daerah diarahkan untuk mewujudkan kesejahteraan masyarakat. Pelaksanaan pengelolaan keuangan daerah dimulai dari perencanaan, penatausahaan, pelaksanaan, pelaporan, pertanggungjawaban, dan pengawasan keuangan daerah. Pelaksanaan pengelolaan daerah yang baik merupakan wujud keberhasilan otonomi daerah dan keberhasilan pemerintan daerah dalam mewujudkan good governance. Undang-Undang Nomor 14 tahun 2008 tentang Keterbukaan Informasi Publik menjelaskan penyelenggara negara bertanggungjawab untuk menyajikan informasi mengenai informasi kegiatan, kinerja, dan laporan keuangan pemerintah kepada masyarakat. Pemerintah daerah sebagai pelaksana kegiatan pemerintahan dituntut untuk meningkatkan akuntabilitas dan transparansi terutama pada pengelolaan laporan keuangan pemerintah daerah. 
Laporan keuangan memiliki peran penting untuk mengurangi konflik kepentingan antara agen dan prinsipal. Berdasarkan Peraturan Pemerintah Nomor 71 tahun 2010 tentang Standar Akuntansi Pemerintahan, pemerintah wajib menyajikan 7 laporan keuangan. Pengungkapan laporan keuangan terdiri dari pengungkapan wajib dan pengungkapan sukarela. Pengungkapan wajib merupakan pengungkapan informasi karena adanya peraturan yang ditetapkan oleh pemerintah (Setyaningrum \& Syafitri, 2012), sedangkan Pengungkapan sukarela merupakan pengungkapan sebagai tambahan informasi dilakukan diluar item-item yang wajib bagi pengguna laporan keuangan (Setyaningrum \& Syafitri, 2012). Item pengungkapan wajib yang disajikan oleh pemerintah yang terdiri dari: PSAP 04 yang membahas tentang pengungkapan di dalam CaLK, PSAP 05 mengenai akuntansi persediaan, PSAP 06 mengenai akuntansi investasi, PSAP 07 mengenai akuntansi aset tetap, PSAP 08 mengenai akuntansi konstruksi dalam pengerjaan, dan PSAP 09 mengenai akuntansi kewajiban (Iqbal, Gundono, \& Ritonga, 2018).

Ikhtisar hasil pemeriksaan semester yang dilakukan oleh BPK terhadap LKPD tahun 2015 - 2018 masih terdapat pemerintah daerah yang belum mendapat opini WTP disebabkan terdapat kelemahan dalam penyajian laporan keuangan sesuai SAP (bpk.go.id/ihps). Berdasarkan studi pendahuluan yang dilakukan pada LKPD Kabupaten/Kota di Kalimantan Selatan tahun 2015 sampai dengan 2018 diperoleh data sebagai berikut:

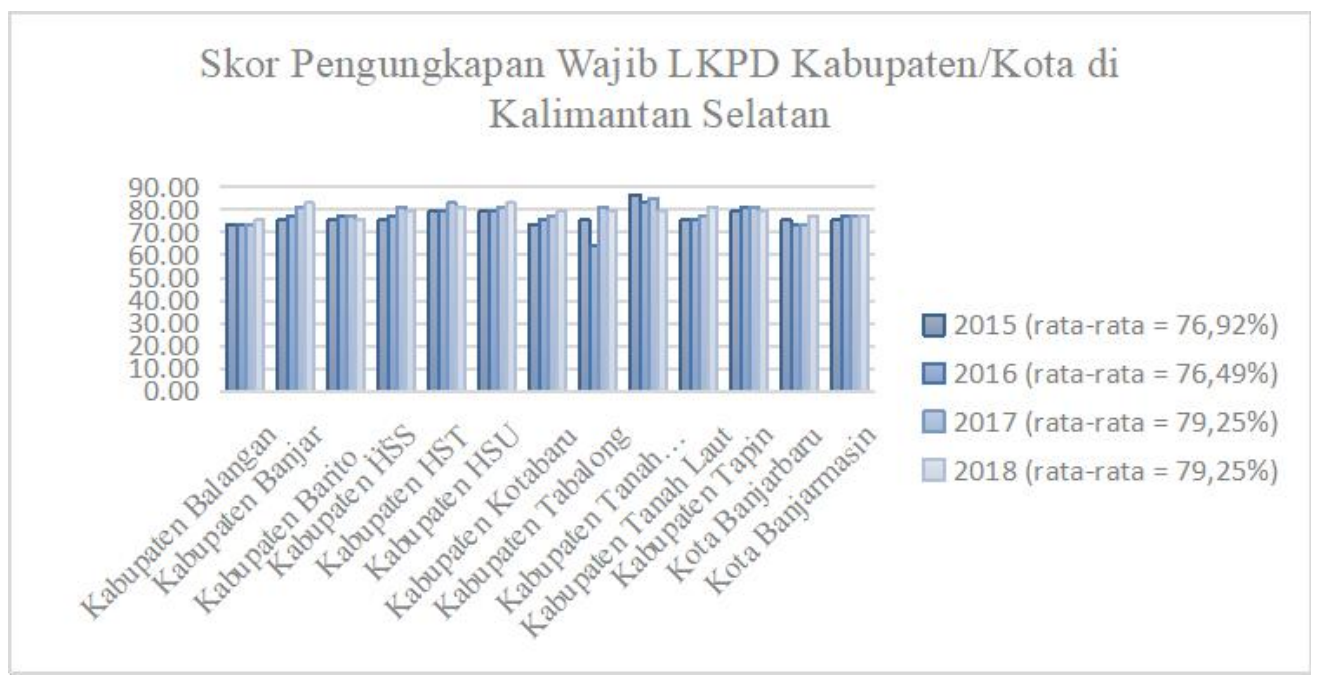

Variabel ketergantungan daerah mencerminkan perbandingan jumlah pendapatan transfer yang diperoleh dari pemerintah pusat dengan jumlah pendapatan daerah. Menurut Menteri Keuangan Sri Mulyani (2019) ketergantungan pemerintah daerah kabupaten/kota masih sangat tinggi (kemenkeu.go.id). Semakin tinggi ketergantungan suatu daerah maka akan semakin tinggi pula tingkat informasi yang diungkapkan dalam laporan keuangan pemerintah daerah sebagai bentuk pertanggungjawaban atas dana yang didapat (Putri \& Arza, 2019).

Kekayaan pemerintah daerah merupakan ukuran kemakmuran daerah yang di proksikan dari Pendapatan Asli Daerah (PAD) (Feriyanti, Hermanto, \& Suransi, 2015). Menurut Badan Kebijakan Fiskal Kementerian Keuangan RI (2019) Pajak Daerah dan Retribusi Daerah (PDRD) dalam Pendapatan Asli Daerah (PAD) ataupun total pendapatan secara keseluruhan masih perlu ditingkatkan (fiskal.kemenkeu.go.id). Semakin besar jumlah PAD yang diperoleh maka pemerintah daerah akan semakin terdorong untuk mengungkapkan laporan keuangan secara lengkap (Setyowati, 2016).

Belanja daerah menurut UU No. 17 tahun 2003 tentang keuangan negara adalah kewajiban pemerintah daerah yang diakui sebagai pengurang nilai kekayaan bersih. Menurut 
Perwakilan Direktorat Jenderal Perimbangan Keuangan, Irfan Sofi (2020) melihat dari peningkatan belanja daerah, belanja modal persentasenya masih kecil jika dibandingkan dengan belanja pegawai serta belanja barang dan jasa, padahal belanja modal merupakan salah satu belanja untuk pembangunan infrastruktur (www.kemenkeu.go.id). Tingginya belanja daerah dalam suatu pemerintah daerah maka pengungkapan konten informasi laporan keuangan pemerintah daerah juga akan tinggi (Pratama, Werastuti, \& Sujana, 2015).

Salah satu alat ukur untuk menunjukkan tingkat kemajuan masyarakat adalah Indeks Pembangunan Manusia (IPM) (Najah \& Purwati, 2019). Berdasarkan data yang diperoleh dari United Nation Development Programme tingkat pembangunan di indonesia mendapat peringkat ke 111 dari 189 negara, dari data tersebut menunjukkan bahwa tingkat pembangunan manusia di Indonesia tergolong rendah dibandingkan negara lain, di kawasan Asia Tenggara peringkat IPM Indonesia masih dibawah Singapura, Brunei Darusalam, Malaysia, Thailand dan Filipina (www.undp.org). Semakin pembangunan manusia maka keinginan masyarakat semakin beragam sehingga menibulkan tuntutan terhadap pemerintah daerah untuk mengungkapkan laporan keuangan lebih luas dan rinci (Setyowati, 2016).

Berdasarkan fenomena gap yang terjadi dan ketidakkonsistenan mengenai faktorfaktor yang mempengaruhi tingkat pengungkapan wajib LKPD, maka peneliti termotivasi untuk menilai sejauh mana tingkat kepatuhan pengungkapan laporan keuangan pemerintah daerah di Provinsi Kalimantan Selatan untuk memenuhi aspek transparansi dan akuntabilitas. Tujuan penelitian ini untuk menguji dan menganalisis pengaruh ketergantungan daerah, kekayaan daerah, belanja daerah dan IPM terhadap tingkat pengungkapan wajib Laporan Keuangan Pemerintah Daerah pada Kabupaten/Kota di Kalimantan Selatan tahun anggaran 2015-2018.

Penelitian ini diharapkan menjadi bahan masukan agar dapat meningkatkan kesadaran pemerintah daerah untuk memenuhi aspek transparansi dan akuntabilitas. Bagi pemerintah pusat penelitian ini dapat dijadikan tolak ukur penerapan Standar Akuntansi Pemerintahan dalam laporan keuangan pemerintah daerah (LKPD). Bagi masyarakat penelitian ini dapat menjadi sumber informasi untuk mengetahui tingkat pengungkapan LKPD di Provinsi Kalimantan Selatan. Bagi peneliti yang akan datang penelitian ini dapat dijadikan dorongan serta bahan reverrensi agar meneliti lebih banyak lagi mengenai faktor-faktor yang memperngaruhi tingkat pengungkapan wajib LKPD.

\section{Teori Agensi}

Teori agensi menjelaskan hubungan perjanjian antara pihak yang memberi kewenangan (principal) dengan pihak yang diberi kewenangan (agent) untuk menjalankan kepentingan kedua belah pihak serta pendelegasian tugas kepada pihak agen (Putri \& Arza, 2019). Pihak yang bertindak sebagai agen di pemerintaha daerah adalah penyelenggara pemerintahan, sedangkan rakyat bertindak sebagai prinsipal yang memberikan amanat kepada pengelola pemerintah daerah untuk menjalankan pemerintahan agar kesejahteraan rakyat dapat tercapai (Feriyanti, Hermanto, \& Suransi, 2015). Adanya hubungan agen dan prinsipal ini tidak menutup kemungkinan timbulnya informasi yang asimetris, sehingga diperlukan transparansi pertanggungjawaban keuangan berupa Laporan Keuangan Pemerintah Daerah (LKPD).

\section{Laporan Keuangan Pemerintah Daerah}

Dalam pelaksanaan desentralisasi, pemerintah daerah memiliki kewajiban untuk mengurus rumah tangganya sendiri baik dalam segi pengelolaan keuangan maupun dalam segi administratif. Laporan keuangan berfungsi untuk menyajikan nilai sumber daya ekonomi yang digunakan serta untuk menentukan tingkat ketaatan pemerintah daerah terhadap peraturan perundang-ungangan yang telah ditetapkan. Penyajian laporan keuangan berdasarkan basis akrual telah diatur dalam PP Nomor 71 Tahun 2010 tentang Standar Akuntansi 
Pemerintahan yang terdiri dari komponen-komponen laporan keuangan laporan pelaksanaan anggaran (budgetary reports) dan laporan finansial.

\section{Pengungkapan Laporan Keuangan Pemerintah Daerah (LKPD)}

Pengungkapan laporan keuangan mengandung arti penyajian informasi secara jelas yang dapat mewakili keadaan suatu entitas sesuai dengan keadaan yang sebenarnya. Laporan keuangan setidaknya disajikan mencakup jenis laporan dan elemen informasi yang diharuskan oleh ketentuan perundang-undangan. Transparansi laporan keuangan daerah diperlukan agar pengawasan terhadap penyelenggara negara dapat dilakukan secara objektif.

\section{Ketergantungan Daerah}

Ketergantungan daerah adalah seberapa besar pemerintah daerah dapat menjalankan program kerja yang telah dirancang dengan dana transfer dari pemerintah pusat (Heriningsih \& Rusherlistyani, 2013). Pendapatan transfer yang diperoleh pemerintah daerah antara lain: dana bagi hasil, dana alokasi umum, dan dana alokasi khusus. Selain sebagai sumber utama penerimaan daerah, pendapatan transfer dari pusat juga berfungsi untuk menjaga dan menjamin tercapainya standar pelayanan minimum di seluruh negeri (Halim \& Kusufi, 2014).

Menurut Halim (2016, hal. 124-125) ada beberapa alasan perlunya transfer keuangan dari pusat ke daerah antara lain: (1) Untuk mengatasi persoalan ketimpangan fiskal vertikal (vertikal fiscal imbalance), (2) Untuk mengatasi persoalan ketimpangan fiskal horizontal (horizontal fiscal imbalance), (3) Agar tercapainya standar pelayanan minimum di setiap daerah, (4) Untuk mengatasi persoalan yang timbul dari menyebar atau melimpahnya efek pelayanan publik (inter-jurisdictional spill-over effects), (5) Untuk mencapai stabilisasi.

\section{Kekayaan Daerah}

Kekayaan daerah merupakan seberapa besar kinerja pemerintah daerah dalam menghasilkan pendapatan yang berasal dari PAD dan lain-lain pendapatan yang sah (Ramdhani, 2016). PAD diberikan agar pemerintah daerah memiliki keleluasaan untuk menggali pendanaan dari melalui potensi daerahnya sendiri sebagai perwujudan asas desentralisasi. Sumber utama pendapatan asli daerah adalah pajak dan retribusi daerah yang dipungut dari masyarakat. Sumber-sumber Pendapatan Asli Daerah (PAD) diatur menurut Undang-Undang Nomor 28 tahun 2009 tentang Pajak Daerah dan Retribusi Daerah.

\section{Belanja Daerah}

Belanja daerah menurut Undang-Undang Nomor 23 tahun 2014 adalah kewajiban daerah yang diakui sebagai pengurang nilai kekayaan bersih dalam periode tertentu. Belanja daerah terdiri dari belanja modal, belanja operasi, dan belanja tidak terduga. Belanja daerah digunakan untuk meningkatkan kualitas hidup masyarakat dengan cara meningkatkan pelayanan dasar, fasilitas pelayanan kesehatan, fasilitas sosial, fasilitas pendidikan, fasilitas umum, dan pengembangan sistem jaminan sosial (Puspita \& Martani, 2012).

\section{Indeks Pembangunan Manusia (IPM)}

Menurut Badan Pusat Statistik, IPM merupakan indikator untuk mengukur keberhasilan pemerintah dalam membangun kualitas hidup manusia. IPM menilai kualitas pembangunan manusia baik dari kondisi fisik (kesejahteraan dan kesehatan) dan non-fisik (pengetahuan). Sebagai ukuran kinerja, terdapat tiga dimensi dasar dalam pengukuran IPM yaitu umur panjang dan sehat, pengetahuan, dan kehidupan yang layak. Semakin tinggi kualitas sumber daya manusia maka dapat menciptakan kesadaran masyarakat akan kebutuhan informasi keuangan daerah. 


\section{Pengaruh Ketergantungan Daerah Terhadap Tingkat Pengungkapan Wajib Laporan Keuangan Pemerintah Daerah}

Ketergantungan daerah berkaitan dengan kemampuan pemerintah daerah dalam menjalankan program kerja dengan menggunakan dana transfer dari pemerintah pusat (Heriningsih \& Rusherlistyani, 2013). Melalui dana transfer, pemerintah daerah didorong untuk meningkatkan kepercayaan pemerintah pusat dengan meningkatkan transparansi sehigga dapat menunjukkan kepatuhan terhadap peraturan yang berlaku (Najah \& Purwati, 2019). Ketergantungan daerah yang tinggi terhadap dana dari pemerintah pusat maka informasi yang diungkapkan akan semakin tinggi pula karena adanya tanggungjawab pemerintah daerah untuk mengungkapkan pengelolaan dana transfer yang berasal dari transfer pusat.

H1: Ketergantungan daerah berpengaruh terhadap tingkat pengungkapan wajib laporan keuangan pemerintah daerah.

\section{Pengaruh Kekayaan Daerah Terhadap Tingkat Pengungkapan Wajib Laporan Keuangan Pemerintah Daerah}

Kekayaan daerah merupakan seberapa besar kinerja pemerintah daerah dalam menghasilkan pendapatan yang berasal dari PAD dan lain-lain pendapatan yang sah (Ramdhani, 2016). Menurut Direktoral Jenderal Perimbangan Keuangan (2019) Pendapatan Asli Daerah (PAD) terdiri dari pajak daerah, retribusi daerah, hasil pengelolaan kekayaan daerah yang dipisahkan, dan lain-lain PAD yang sah. PAD diberikan agar pemerintah daerah memiliki keleluasaan untuk menggali pendanaan dari melalui potensi daerahnya sendiri. Semakin besar penerimaan daerah maka dapat dikatakan bahwa partisipasi masyarakat untuk membayar pajak dan retribusi juga semakin tinggi. Oleh karena itu, pemerintah daerah akan terdorong untuk meningkatkan pengungkapan laporan keuangan (Setyowati, 2016).

H2: Kekayaan daerah berpengaruh terhadap tingkat pengungkapan wajib laporan keuangan pemerintah daerah.

\section{Pengaruh Belanja Daerah Terhadap Tingkat Pengungkapan Wajib Laporan Keuangan Pemerintah Daerah}

Belanja daerah digunakan untuk melindungi dan meningkatkan kualitas hidup masyarakat dengan cara meningkatkan pelayanan dasar, fasilitas sosial, fasilitas pendidikan, fasilitas umum, fasilitas pelayanan kesehatan dan pengembangan sistem jaminan sosial (Puspita \& Martani, 2012). Semakin besar anggaran yang dikeluarkan pemerintah maka pelayanan publik semakin baik. Ketika pelayanan publik semakin tinggi, maka pemerintah daerah memiliki motivasi untuk meningkatkan pengungkapan informasi laporan keuangan (Amaliah \& Haryanto, 2019). Melalui pengungkapan laporan keuangan daerah, masyarakat dapat menilai apakah pelaksanaan belanja daerah sudah dilakukan secara efektif dan efisien, sekaligus menilai apakah sesecara keseluruhan belanja tersebut telah digunakan untuk kepentingan pelayanan umum masyarakat.

H3: Belanja daerah berpengaruh terhadap tingkat pengungkapan wajib laporan keuangan pemerintah daerah.

\section{Pengaruh Indeks Pembangunan Manusia (IPM) Terhadap Tingkat Pengungkapan Wajib Laporan Keuangan Pemerintah Daerah}

IPM merupakan indikator strategis yang dapat digunakan untuk menentukan kualitas penduduk dalam suatu wilayah dalam hal harapan hidup, intelektualitas dan standar hidup yang layak (Badan Pusat Statistik, 2015). Kualitas sumber daya manusia yang tinggi dapat menciptakan kesadaran masyarakat akan kebutuhan informasi keuangan daerah. Semakin besar nilai pembangunan masyarakat, maka keinginan masyarakat akan semakin beragam 
untuk dipenuhi, hal tersebut akan menimbulkan motivasi pengelola pemerintah untuk melakukan pengungkapan yang lebih luas dan detail (Najah \& Purwati, 2019).

H4: Indeks Pembangunan Manusia (IPM) berpengaruh terhadap tingkat pengungkapan wajib laporan keuangan pemerintah daerah.

\section{METODE PENELITIAN}

Penelitian ini merupakan penelitian asosiatif dengan pendekatan kuantitatif. Populasi penelitian terdiri dari seluruh Pemerintah Kabupaten/Kota di Kalimantan Selatan periode 2015-2018 dan telah diperiksa oleh BPK RI. Teknik pengumpulan data dengan cara dokumentasi. Data laporan keuangan pemerintah daerah diperoleh dari BPK perwakilan Kalimantan Selatan dan data skor IPM diperoleh dari BPS Provinsi Kalimantan Selatan. Jumlah kabupaten/kota yang ada di Kalimantan Selatan sebanyak 13 terdiri dari 11 pemerintah kabupaten dan 2 pemerintah kota. Teknik pengambilan sampel menggunakan pendekatan nonprobability sampling metode purposive sampling. Berdasarkan kriteria yang telah ditetapkan diperoleh jumlah akhir yang pemerintah daerah yang di observasi dari 13 dikalikan 4 tahun periode pengamatan sehingga laporan keuangan yang akan di teliti sebanyak 52 LKPD.

\section{Definisi Operasional Variabel Penelitian}

Penelitian ini menggunakan variabel dan indikator sebagai berikut:

Tabel 1

Indikator variabel penelitian

\begin{tabular}{|c|c|c|}
\hline & Variabel & Rumus \\
\hline \multirow[t]{4}{*}{$\begin{array}{l}\text { Independen } \\
(\mathrm{X})\end{array}$} & $\begin{array}{l}\text { Ketergantungan } \\
\text { Daerah }\left(\mathrm{X}_{1}\right)\end{array}$ & $\begin{array}{l}\text { Ketergantungan daerah menurut Invalid source specified. } \\
=\frac{\text { pendapatan transfer }}{\text { total pendapatan daerah }} \times 100 \%\end{array}$ \\
\hline & Kekayaan Daerah $\left(\mathrm{X}_{2}\right)$ & $\begin{array}{l}\text { Kekayaan Daerah Menurut (Putri \& Arza, 2019) } \\
=\text { Ln (Realisasi Pendapatan Asli Daerah) }\end{array}$ \\
\hline & Belanja Daerah $\left(\mathrm{X}_{3}\right)$ & $\begin{array}{l}\text { Belanja Daerah menurut (Ramdhani, 2016) } \\
\quad=\text { Ln(Realisasi Belanja })\end{array}$ \\
\hline & $\operatorname{IPM}\left(X_{4}\right)$ & $\begin{array}{l}\text { Indeks Pembangunan Manusia (IPM) menurut (Jessica \& } \\
\text { Suhartono, 2020) } \\
\quad=(\text { Persentase IPM) }\end{array}$ \\
\hline $\begin{array}{l}\text { Dependen } \\
\text { (Y) }\end{array}$ & $\begin{array}{l}\text { Tingkat } \\
\text { Pengungkapan Wajib } \\
\text { LKPD }\end{array}$ & $\begin{array}{l}\text { Pengungkapan LKPD (Maulana \& Handayani, 2015) } \\
\quad=\frac{\text { Jumlah item yang diungkapkan }}{\text { Total iten yang harus diungkapkan }} \text { X } 100\end{array}$ \\
\hline
\end{tabular}

\section{Teknik Analisis Data}

Analisis data menggunakan analisis regresi linier berganda. Model persamaan penelitian sebagai berikut:

$$
Y=\alpha+\beta_{1} X_{1}+\beta_{2} X_{2}+\beta_{3} X_{3}+\beta_{4} X_{4}+e
$$


Keterangan:

$\mathrm{Y}=$ Tingkat pengungkapan wajib LKPD

$\alpha=$ Konstanta

$\beta_{\mathrm{n}}=$ Koefisien Regresi Variabel

$\mathrm{X}_{1}=$ Ketergantungan Daerah

$\mathrm{X}_{2}=$ Kekayaan Daerah

$\mathrm{X}_{3}=$ Belanja Daerah

$\mathrm{X}_{4}=$ IPM

$\mathrm{e}=$ Standar Error

HASIL DAN PEMBAHASAN

Statistik Deskriptif

Tabel 2

Statistik Deskriptif

\begin{tabular}{|c|c|c|c|c|c|c|}
\hline & & $\mathrm{N}$ & $\begin{array}{l}\text { Minim } \\
\text { um }\end{array}$ & $\begin{array}{l}\text { Maxim } \\
\text { um }\end{array}$ & Mean & $\begin{array}{c}\text { Std. } \\
\text { Deviation }\end{array}$ \\
\hline DISCI & & 5 & 6415 & 8679 & 77,97 & 3,712 \\
\hline DINCE & 2 & & & & 53 & 40 \\
\hline Ketergantung & & 5 & 60,33 & 84.26 & 72,09 & 5,051 \\
\hline an Daerah & 2 & & & & 40 & 35 \\
\hline Kekayaan & & 5 & 24.63 & 26.51 & 25,55 & ,4265 \\
\hline Daerah & 2 & & & 20,31 & 85 & 6 \\
\hline Belanja & & 5 & 27,45 & 28,14 & 27,79 & ,1812 \\
\hline Daerah & 2 & 5 & & & 246001 & 8 \\
\hline IPM & 2 & 5 & 62,49 & 78,83 & $04^{09,01}$ & 53 \\
\hline $\begin{array}{l}\text { Valid N } \\
\text { (listwise) }\end{array}$ & 2 & 5 & & & & \\
\hline
\end{tabular}

Tabel 3

Hasil Regresi

\begin{tabular}{|c|c|c|c|c|c|}
\hline \multirow[t]{2}{*}{ Model } & \multicolumn{2}{|c|}{$\begin{array}{l}\text { Unstandardized } \\
\text { Coefficients }\end{array}$} & \multirow{2}{*}{$\begin{array}{r}\text { Standardized } \\
\text { Coefficients } \\
\text { Beta }\end{array}$} & \multirow[t]{2}{*}{$\mathrm{t}$} & \multirow[t]{2}{*}{ Sig. } \\
\hline & $\mathrm{B}$ & Std. Error & & & \\
\hline \multirow[t]{2}{*}{ (Constant) } & 21 & 78 & & 2 & \\
\hline & 6,186 & 741 & & ,746 & 009 \\
\hline Ketergantungan & - & ,14 &,- 443 & - & \\
\hline Daerah & ,326 & 4 & & 2,266 & 028 \\
\hline Kekayaan & - & 2,6 &,- 054 & - & \\
\hline Daerah & ,467 & 45 & & ,176 & 861 \\
\hline \multirow[t]{2}{*}{ Belanja Daerah } & - & 3,7 &,- 149 & - & \\
\hline & 3,047 & 11 & & ,821 & 416 \\
\hline \multirow[t]{2}{*}{ IPM } & - & 18 &,- 286 & - & \\
\hline & ,263 & 0 & & 1,467 & 149 \\
\hline
\end{tabular}

Sumber: Data Diolah 2021

Berdasarkan Tabel 3 d iatas dapat dianalisis model persamaan sebagai berikut:

$$
Y=216,186-0,326 X_{1}-0,467 X_{2}-3,047 X_{3}-0,263 X_{4}+\varepsilon
$$




\section{Uji Asumsi Klasik}

\section{Uji Normalitas}

Hasil uji normalitas menggunakan pendekatan One-Sample Kolmogorov-Smirnov Test diperoleh nilai sig. sebesar 0,200 dimana nilai tersebut $>0,05$ sehingga dapat dinyatakan bahwa data berdistribusi normal.

\section{Uji Multikolinearitas}

Hasil uji multikolinearitas diperoleh nilai sebagai berikut:

Tabel 4

Hasil Uji Multikolinearitas

\begin{tabular}{lcc}
\hline \multicolumn{1}{c}{ Variabel } & Tolerance & $\begin{array}{l}\text { Variance } \\
\text { Factor (VIF) }\end{array}$ \\
\hline Ketergantungan Daerah (X1) & 0,451 & Inflation \\
Kekayaan Daerah (X2) & 0,187 & 5,354 \\
Belanja Daerah (X3) & 0,525 & 1,904 \\
\hline Indeks Pembangunan Manusia (X4) & 0,454 & 2,201 \\
\hline
\end{tabular}

Sumber: Data Diolah 2021

Berdasarkan hasil pengujian disimpulkan tidak terdeteksi gejala multikolinearitas karena nilai tolerance masing-masing variabel $\geq 0,10$ dan nilai $\mathrm{VIF} \leq 10$.

\section{Uji Heteroskedastisitas}

Hasil uji heteroskedastisitas menggunakan uji glejser diperoleh nilai signifikasi sebagai berikut:

Tabel 5

Hasil Uji Heteroskedastisitas

\begin{tabular}{lcc}
\hline \multicolumn{1}{c}{ Variabel } & Sig. & Keterangan \\
\hline Ketergantungan Daerah (X1) & 0,589 & Tidak heteroskedastisitas \\
Kekayaan Daerah (X2) & 0,737 & Tidak heteroskedastisitas \\
Belanja Daerah (X3) & 0,420 & Tidak heteroskedastisitas \\
Indeks Pembangunan Manusia (X4) & 0,666 & Tidak heteroskedastisitas \\
\hline
\end{tabular}

Sumber: Data Diolah 2021

Berdasarkan hasil uji glejser tersebut, menunjukkan bahwa seluruh variabel mempunyai nilai signifikan diatas 0,05 .

\section{Uji Autokorelasi}

Hasil uji autokorelasi nilai DW yang diperoleh sebesar 1,499 sehingga dapat dapat disimpulkan bahwa model regresi bebas gejala autokorelasi. Dengan menggunakan ketentuan berikut: 
Tabel 6

Nilai Uji Durbin-Watson (Uji DW)

\begin{tabular}{cc}
\hline Nilai Durbin-Watson (DW) & Interpretasi \\
\hline$-2 \leq \mathrm{DW} \leq 2$ & Tidak terjadi autokorelasi \\
$\mathrm{DW}<-2$ & Terjadi autokorelasi positif \\
$\mathrm{DW}>+2$ & Terjadi autokorelasi negatif \\
\hline
\end{tabular}

Sumber : (Bahri, 2018)

\section{Koefisien Determinasi $\mathbf{R}^{2}$}

Koefisien determinasi digunakan untuk mengetahui seberapa besar kemampuan variabel bebas dalam menerangkan variabel terikat. Nilai determinasi ditentukan dengan nilai Adjust R Square. Koefisien determinasi dapat dilihat pada tabel berikut:

Tabel 7

Hasil Uji Koefisien Determinasi

\begin{tabular}{ccrrr}
\hline Model & R & R Square & \multicolumn{1}{c}{ Adjusted R } & Std. Error of the Estimate \\
1 &, $435^{\mathrm{a}}$ &, 189 &, 120 & 3,48243 \\
\hline Sumber: Data Diolah 2021 & & & &
\end{tabular}

Nilai koefisien determinasi sebesar 0,189 atau $18,9 \%$ yang menunjukkan bahwa ketergantungan daerah, kekayaan daerah, belanja daerah dan IPM dalam menjelaskan variasi tingkat pengungkapan wajib LKPD sebesar $18,9 \%$ sedangkan $81,1 \%$ dijelaskan oleh variabel lain yang tidak diteliti dalam penelitian ini.

\section{Uji Statistik F}

Uji statistik $\mathrm{F}$ merupakan suatu pengujian yang digunakan untuk menentukan pengujian hipotesis semua variabel independen yang dimasukkan dalam model berpengaruh secara bersama-sama terhadap variabel dependen dan untuk menentukan kelayakan model. Cara melakukan pengambilan keputusan uji simultan (Uji F) adalah dengan mengukur nilai probabilitas signifikansi dan membandingkan nilai $\mathrm{F}$ hasil perhitungan dengan nilai $\mathrm{F}$ menurut tabel. Jika nilai $\mathrm{F}$ hitung lebih besar daripada $\mathrm{F}$ tabel dan jika nilai probabilitas signifikansi $\leq$ 0,05 maka semua variabel independen secara serentak dan signifikan mempengaruhi variabel dependen (Ghozali, 2018). Uji F dapat dilihat pada tabel sebagai berikut:

\begin{tabular}{|c|c|c|c|c|c|c|}
\hline \multicolumn{7}{|c|}{$\begin{array}{c}\text { Tabel } 8 \\
\text { Hasil Uji Statistik F }\end{array}$} \\
\hline & Model & $\begin{array}{l}\text { Sum Of } \\
\text { Squares }\end{array}$ & df & $\begin{array}{l}\text { Mean } \\
\text { Square }\end{array}$ & $\mathbf{F}$ & Sig. \\
\hline & Regression & 132,894 & 4 & 33,223 & 2,740 &, $040^{\mathrm{b}}$ \\
\hline & Residual & 569,984 & 47 & 12,127 & & \\
\hline & Total & 702,878 & 51 & & & \\
\hline
\end{tabular}

Sumber: Data Diolah 2021

Berdasarkan uji $\mathrm{F}$ yang dilakukan, diperoleh $\mathrm{F}$ hitung sebesar 2,740 dengan sig. 0,040, dimana sig. $0,040<0,05$. Selain itu pengukuran juga dilakukan dengan membandingkan nilai

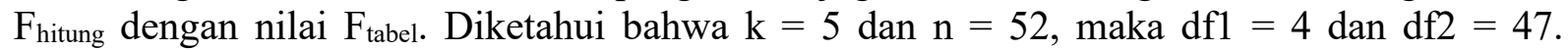
Sehingga didapatkan nilai $F_{\text {tabel }}$ sebesar 2,57, sehingga dapat dilihat bahwa $F_{\text {hitung }}$ lebih sebesar daripada $F$ tabel 2,740 $>2,57$. Maka semua variabel independen dalam penelitian ini secara serentak berpengaruh terhadap variabel dependen. 


\section{Uji Statistik t}

Uji statistik $\mathrm{t}$ merupakan pengujian untuk menunjukkan seberapa jauh pengaruh variabel independen secara individu dalam menerangkan variabel dependen (Ghozali, 2018). Jika nilai signifikansi $<0,05$ maka hipotesis diterima atau variabel independen berpengaruh secara signifikan terhadap variabel dependen. Cara lain yang dapat digunakan yaitu dengan membandingkan nilai statistik $t$ dengan titik kritis menurut tabel, apabila nilai $t_{\text {hitung }}>t_{\text {tabel }}$ maka variabel independen secara individu mempengaruhi variabel dependen (Ghozali, 2018). Uji T dapat dilihat pada tabel sebagai berikut:

Tabel 9

Hasil Uji Statistik T

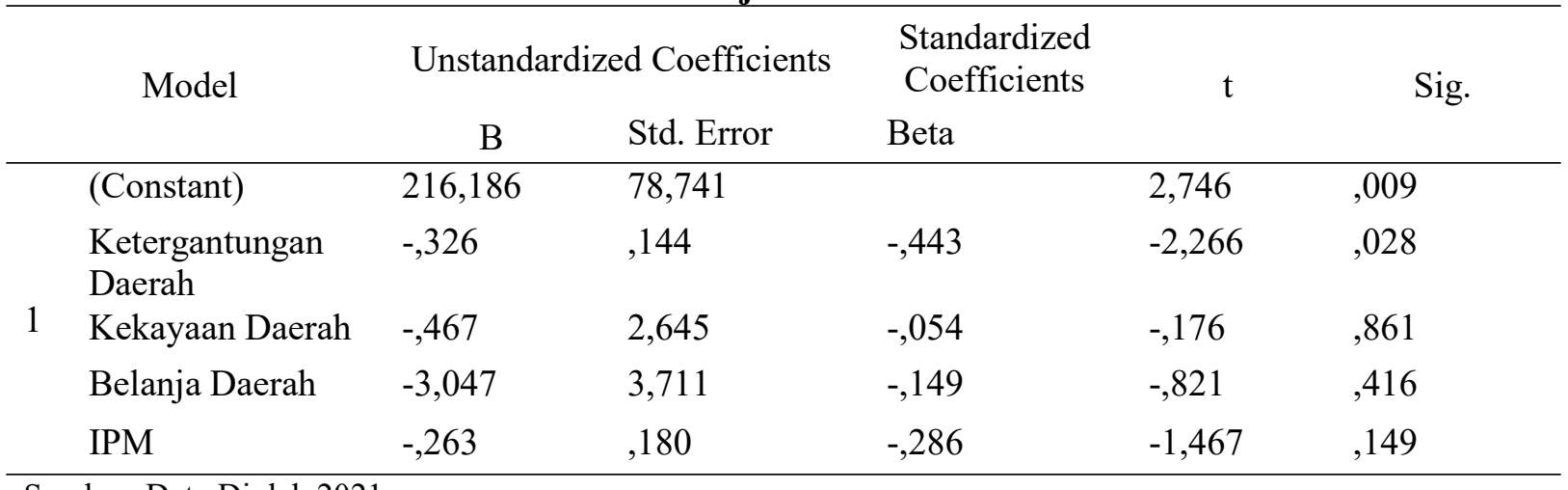

Sumber: Data Diolah 2021

Dari pengujian menggunakan regresi linier berganda diperoleh hasil signifikansi dengan pembahasan sebagai berikut:

\section{Pengaruh Ketergantungan Daerah Terhadap Tingkat Pengungkapan Wajib Laporan Keuangan Pemerintah Daerah}

Berdasarkan hasil pengujian ketergantungan daerah berpengaruh signifikan terhadap tingkat pengungkapan wajib LKPD. Hal ini sesuai dengan hasil pengujian analisis regresi linier berganda dimana nilai $t_{\text {hitung }}$ lebih besar daripada $t_{\text {tabel }}(-2,266>2,0117)$ dan nilai signifikan yang lebih kecil dari taraf signifikan $(0,028<0,05)$. Nilai thitung yang negatif menunjukkan bahwa terdapat arah yang berlawanan, yang berarti tingginya nilai ketergantungan daerah tidak diiringi dengan peningkatan pengungkapan pengungkapan wajib laporan keuangan. Hal ini diduga karena kurangnya kontrol dari pemerintah pusat terhadap dana perimbangan yang diberikan, sehingga pemerintah daerah kurang termotivasi untuk meningkatkan pengungkapan dalam laporan keuangan pemerintah daerah mereka. Sehingga semakin tinggi ketergantungan daerah terhadap pusat tidak serta meningkatkan tingkat pengungkapan wajib LKPD.

\section{Pengaruh Kekayaan Daerah Terhadap Tingkat Pengungkapan Wajib Laporan Keuangan Pemerintah Daerah}

Berdasarkan hasil pengujian kekayaan daerah tidak berpengaruh signifikan terhadap tingkat pengungkapan wajib laporan keuangan pemerintah daerah. Sesuai dengan hasil pengujian analisis regresi linier berganda dimana nilai $t_{\text {hitung }}$ lebih kecil daripada $t_{\text {tabel }}(-0,176<$ $2,0117)$ dan nilai signifikan yang lebih besar dari taraf signifikan $(0,861>0,05)$.

Variabel kekayaan daerah yang tidak berpengaruh signifikan merupakan akibat penerimaan pendapatan daerah yang berasal dari pajak dan retribusi yang belum optimal. data yang diperoleh dari Kajian Fiskal Regional tahun 2018 oleh Kanwil Direktorat Jenderal Perbendaharaan Provinsi Kalimantan Selatan bahwa realisasi penerimaan pendapatan asli daerah seluruh pemerintah daerah di Provinsi Kalimantan Sealatan tahun 2017 dan 2018 dapat 
disimpulkan bahwa masyarakat yang berperan sebagai agen belum sepenuhnya menjalankan kewajiban untuk membayar pajak dan retribusi, sehingga target penerimaan pendapatan asli daerah belum dapat tercapai $100 \%$, akibatnya peran pendapatan asli daerah kurang memotivasi pengelola pemerintah daerah dalam melakukan pengungkapan wajib LKPD.

\section{Pengaruh Belanja Daerah Terhadap Tingkat Pengungkapan Wajib Laporan Keuangan Pemerintah Daerah}

Berdasarkan hasil pengujian belanja daerah tidak berpengaruh signifikan terhadap tingkat pengungkapan wajib LKPD. Sesuai dengan hasil pengujian analisis regresi linier berganda dimana nilai thitung lebih kecil daripada tabel $(-0,821<2,0117)$ dan nilai signifikan yang lebih besar dari taraf signifikan $(0,416>0,05)$.

Belanja daerah yang tinggi tidak mencerminkan tingkat pelayanan yang tinggi, karena belanja belum dilakukan secara efektif dan efisien serta secara keseluruhan belum digunakan untuk meningkatkan pelayanan umum kepada masyarakat (Ramdhani, 2016). Menurut Perwakilan Direktorat Jenderal Perimbangan Keuangan, Irfan Sofi (2020) belanja daerah belum dilakukan secara efektif dan efisien diindikasikan dari peningkatan belanja daerah namun persentase belanja modal terbilang lebih kecil dibandingkan belanja pegawai serta belanja barang dan jasa. Berdasarkan data yang diperoleh dari Kajian Fiskal Regional tahun 2018 oleh Kanwil Direktorat Jenderal Perbendaharaan Provinsi Kalimantan Selatan realisasi belanja modal seluruh pemerintah daerah di Provinsi Kalimantan Sealatan tahun 2017 \& 2018 persentase ini lebih kecil jika dibandingkan dengan dengan realisasi belanja pegawai.

\section{Pengaruh Indeks Pembangunan Manusia (IPM) Terhadap Tingkat Pengungkapan Wajib Laporan Keuangan Pemerintah Daerah}

Berdasarkan hasil pengujian IPM tidak berpengaruh signifikan terhadap tingkat pengungkapan wajib laporan keuangan pemerintah daerah. Sesuai dengan hasil pengujian analisis regresi linier berganda dimana nilai thitung lebih kecil daripada $t_{\text {tabel }}(-1,467<2,0117)$ dan nilai signifikan yang lebih besar dari taraf signifikan $(0,149>0,05)$. Tingginnya nilai IPM suatu wilayah justru tidak diikuti dengan peningkatan pengungkapan wajib LKPD, hal ini menunjukkan bahwa masyarakat yang berperan sebagai prinsipal kurang aktif berperan langsung untuk mendorong pemerintah dalam meningkatkan pengungkapan, sehingga pengelola pemerintah daerah kurang termotivasi untuk meningkatkan pengungkapan wajib LKPD mereka.

\section{SIMPULAN DAN SARAN}

Berdasarkan hasil analisa, pengujian hipotesis, dan pembahasan yang telah diuraikan, maka dapat kesimpulan dari penelitian ini adalah: (1) Ketergantungan daerah berpengaruh signifikan terhadap tingkat pengungkapan wajib laporan keuangan pemerintah daerah Kabupaten/Kota di Provinsi Kalimantan Selatan tahun 2015 - 2018, (2) Kekayaan daerah, belanja daerah, Indeks Pembangunan Manusia (IPM) tidak berpengaruh signifikan terhadap tingkat pengungkapan wajib laporan keuangan pemerintah daerah Kabupaten/Kota di Provinsi Kalimantan Selatan tahun 2015 - 2018, (3) Hasil dari penelitian ini juga menunjukkan bahwa rata-rata tingkat pengungkapan wajib laporan keuangan pemerintah daerah Kabupaten/Kota di Provinsi Kalimantan Selatan tahun 2015 - 2018 adalah 77,98\%, dengan rincian 76,92\% (2015), 76,49\% (2016), 79,25\% (2017), dan 79,25\% (2018).

Hasil penelitian ini berkontribusi terhadap penerapan aspek transparansi dan akuntabilitas melalui tingkat pengungkapan wajib LKPD. Bagi pemerintah daerah, penelitian ini diharapkan dapat memberikan bahan masukan agar pemerintah daerah dapat meningkatkan pengungkapan wajib LKPD sesuai dengan (SAP) yang berlaku yaitu Peraturan Pemerintah No. 71 tahun 2010. 


\section{SARAN}

Penelitian ini masih terbatas pada LKPD kabupaten/kota di Provinsi Kalimantan Selatan saja, sehingga penelitian yang akan datang diharapkan lebih luas dan tidak terbatas pada Provinsi Kalimantan Selatan saja serta mempertimbangkan variabel lain yang diduga dapat mempengaruhi tingkat pengungkapan wajib LKPD yang tidak diteliti pada penelitian ini.

\section{DAFTAR PUSTAKA}

Amaliah, E. F., \& Haryanto. (2019). Analisis Faktor-Faktor Yang Memengaruhi Tingkat Pengungkapan Laporan Keuangan Pemerintah Daerah KabupatenKota Di Provinsi Jawa Tengah Tahun 2015-2017. Diponegoro Journal Of Accounting, 8(2), 1-13.

Badan Kebijakan Fiskal Kementerian Keuangan RI. (2019). Evaluasi Pajak Daerah dan Retrebusi Daerah Sebagai Sumber Pendapatan Daerah. Diambil kembali dari https://fiskal.kemenkeu.go.id/.

Badan Pusat Statistik. (2015). Badan Pusat Statistik. Dipetik April Rabu, 2020, dari ipm.bps.go.id: https://ipm.bps.go.id/

Bahri, S. (2018). Metodelogi Penelitian Bisnis - Lengkap Dengan Teknik Pengolahan data SPSS. Yogyakarta: Andi.

BPK RI. (2016). Ikhtisar Hasil Pemeriksaan Semester I (IHPS I) Tahun 2016. Diambil kembali dari www.bpk.go.id.

BPK RI. (2017). Ikhtisar Hasil Pemeriksaan Semester I (IHPS I) Tahun 2017. Diambil kembali dari www.bpk.go.id.

BPK RI. (2018). Ikhtisar Hasil Pemeriksaan Semester I (IHPS I) Tahun 2018. Diambil kembali dari www.bpk.go.id.

BPK RI. (2019). Ikhtisar Hasil Pemeriksaan Semester I (IHPS I) Tahun 2019. Diambil kembali dari www.bpk.go.id.

Direktorat Jenderal Perbendaharaan. (2018). Kajian Fiskal Regional triwulan III 2018. https://djpb.kemenkeu.go.id.

Direktorat Jenderal Perimbangan Keuangan. (2019). Jurnal DEFIS. Jurnal Desentralisasi Fiskal, Ekonomi, dan Keuangan Daerah, V, i-99.

Feriyanti, M., Hermanto, \& Suransi, N. K. (2015). Determinan Kepatuhan pada Ketentuan Pengungkapan Wajib Laporan Keuangan Pemerintah Daerah (Studi Pada Kabupaten/Kota Di Provinsi Nusa Tenggara Barat). Jurnal InFestasi, 11(2), 171-185.

Ghozali, I. (2018). Aplikasi Analisis Multivariate dengan Program IBM SPSS 25. Semarang: Badan Penerbit Universitas Diponegoro.

Halim, A. (2016). Manajemen Keuangan Sektor Publik. Jakarta: Salemba Empat.

Halim, A., \& Kusufi, M. S. (2014). Teori, Konsep, dan Aplikasi Akuntansi Sektor Publik. Jakarta: Salemba Empat.

Heriningsih, S., \& Rusherlistyani. (2013). Faktor-Faktor yang Mempengaruhi Tingkat Pengungkapan Laporan Keuangan Pemerintah Daerah. Jurnal Ekonomi dan Bisnis, 13(2), 11-19.

Iqbal, M., Gundono, \& Ritonga, I. T. (2018). Apakah Kecukupan Pengungkapan telah Dipertimbangkan oleh Badan Pemeriksa Keuangan dalam Perumusan Opini? Jurnal Akuntansi dan Akuntabilitas Publik, 1(1), 17-46.

Mulyani, S. (2019). Ketergantungan Fiskal Daerah dalam Pelaksanaan Desentralisasi Fiskal di Indonesia. Diambil kembali dari kemenkeu.go.id.

Najah, U., \& Purwati, A. S. (2019). Analisis Pengaruh Karakteristik Pemda, Indeks Pembangunan Manusia, dan Kualitas Hasil Audit Terhadap Tingkat Pengungkapan LKPD. Jurnal Kajian Ekonomi \& Keuangan Daerah, 4(2), 70-88.

Pemerintah Republik Indonesia. (2003). Undang-Undang Nomor 17 Tahun 2003 Tentang Keuangan Negara . 
Pemerintah Republik Indonesia. (2008). Undang-Undang Nomor 14 tahun 2008 Tentang Keterbukaan Informasi Publik .

Pemerintah Republik Indonesia. (2009). Undang-Undang Nomor 28 Tahun 2009 Tentang Pajak Daerah dan Retribusi Daerah.

Pemerintah Republik Indonesia. (2010). Peraturan Pemerintah Republik Indonesia Nomor 71 Tahun 2010 Tentang Standar Akuntansi Pemerintahan.

Pemerintah Republik Indonesia. (2014). Undang-Undang Nomor 23 Tahun 2014 Tentang Pemerintah Daerah.

Pratama, K. A., Werastuti, D. N., \& Sujana, E. (2015). Pengaruh Kompleksitas Pemerintah Daerah, Ukuran Pemerintah Daerah, Kekayaan Daerah, dan Belanja Daerah Terhadap Laporan Keuangan Pemerintah Daerah (Studi Pada Pemerintah Kabupaten/Kota di Bali Tahun 2010-2013). e-Journal S1 Ak Universitas Pendidikan Ganesha, 3(1), 1-12.

Puspita, R., \& Martani, D. (2012). Analisis Pengaruh Kinerja dan Karakteristik Pemda Terhadap Tingkat Pengungkapan dan Kualitas Informasi Dalam Website Pemda. skripsi Universitas Indonesia, 1-26.

Putri, W. M., \& Arza, F. I. (2019). Analisis Faktor-Faktor Yang Mempengaruhi Tingkat Pengungkapan Wajib Laporan Keuangan Pemerintah Daerah (Studi Empiris Pada Kabupaten/Kota Se-Sumatera Barat Tahun 2015-2017). Jurnal Eksplorasi Akuntansi, 1(3), 1111-1130.

Ramdhani, D. (2016). Analisis Faktor-Faktor Yang Mempengaruhi Tingkat Pengungkapan Laporan Keuangan Pemerintah Daerah di Propinsi Banten. Jurnal Riset Akuntansi Terpadu, 10(2), 146-160.

Setyaningrum, D., \& Syafitri, F. (2012). Analisis Pengaruh Karakteristik Pemerintah Daerah Terhadap Tingkat Pengungkapan Laporan Keuangan. Jurnal Akuntansi dan Keuangan Indonesia, 9(2), 154-170.

Setyowati, L. (2016). Determinan Yang Mempengaruhi Pengungkapan Laporan Keuangan Pemerintah Daerah. Jurnal Bisnis dan Manajemen, 6(1), 45-62.

Sofi, I. (2020). Pemenuhan Anggaran Infrastruktur di Daerah dan Tantangannya. Diambil kembali dari https://www.kemenkeu.go.id/.

Unnited Nations Development Programme. (2020). Human Development Index (HDI) Ranking. Diambil kembali dari hdr.undp.org: http://hdr.undp.org/ 